\title{
The Impact of Public Capital Investments on the Revenue Growth of Medium Enterprise in Indonesia*
}

\author{
Datius Tirtosuharto \\ Regional Economic and Inflation Division, Economic Research and Monetary Policy Department, \\ Bank of Indonesia, Indonesia
}

\begin{abstract}
Public capital investment represents the role of state and local governments in supporting greater capacity of private enterprises to gain success in a market economy measured by revenue growth. Medium enterprises are considered as the catalysts for economic growth and competitiveness particularly in developing countries due to efficiency and flexibility in an adverse economic environment. Using aggregate data of 30 states (provinces) in Indonesia from 1997-2002, the impact of public capital investment on the revenue growth of medium enterprise is examined. The paper finds that only medium enterprises in the industrial and trading sector benefited from public capital investments and the most optimum capital investment is in transport infrastructure.
\end{abstract}

Abstract: Peran Pemerintah Daerah dalam mendukung peningkatan kapasitas dunia usaha untuk berkompetisi dan meraih sukses di pasar dunia diindikasikan dengan investasi melalui belanja modal. Usaha menengah merupakan penggerak dari pertumbuhan ekonomi dan pendukung daya saing terutama di negara berkembang mengingat keunggulan pada efisiensi dan fleksibilitas dalam kondisi cyclical dari perekonomian. Menggunakan agregat data dari 30 propinsi Indonesia sejak 1997 hingga 2002, studi ini menganalisa dampak dari investasi belanja modal Pemerintah Daerah pada pertumbuhan GDP usaha menengah. Hasil analisis menunjukkan bahwa dampak terbesar dari investasi belanja modal adalah pada usaha menengah di sektor industri dan perdagangan. Sedangkan jenis investasi belanja modal yang paling optimal adalah infrastruktur transportasi. Investasi belanja modal adalah pada usaha menengah di sektor industri serta perdagangan, dan jenis investasi belanja modal yang paling optimal adalah infrastruktur transportasi.

Keywords: business enterprises; economic development; Indonesia; infrastructure; public capital investments

JEL Classification Numbers: H41, H54, O40

\footnotetext{
${ }^{*}$ The views expressed are those of the author and do not necessarily reflect those of Bank Indonesia
} 


\section{Introduction}

Medium enterprise as one of the key pillars in Indonesia's economy is defined as business units that have total assets up to $\$ 20,000$ excluding land and buildings and total 20-99 workers (Tambunan 2007). Medium enterprises play a critical role in the economy due to their ability to support and sustain economic growth by creating employment, stabilizing income, and mobilizing local resources with lower capital. One of the benefits of medium enterprises is thir size and structure that allows more efficiency and flexibility in an adverse economic environment. Medium enterprises also help facilitate the redistribution of income and balance development, which potentially reduces economic disparities along with socio-economic issues in many developing countries.

In addition to wealth creation and social benefits that aim to empower society, medium enterprises through their organizational dynamics also encourage the development of entrepreneurship that focuses on innovation and positive externalities. Medium enterprises provide an opportunity for local people to assess their entrepreneurial ability since they are considered as a seedbed for exploring new ideas and innovation, commercial viability, and market opportunity (Tambunan 2007). Within this context, the dynamics of legal, institutional and policy structure at the macro level are crucial (Audretsch and Keilbach 2004).

From the institutional and macro policy aspect, to support greater capacity for entrepreneurial development at the regional level, there is a role of state and local governments in establishing fiscal incentives through taxes and utilization of capital investment. Yet, the effectiveness of this strategy in many developing countries is still debated considering the inefficiency of government institutions. Fiscal incentives, particularly public capital investments as a critical element to accelerate growth of private enterprises and at the same time sustain economic development, have not been optimally utilized in developing countries. In Indonesia, this problem was evident following the 1997 financial crisis in which the allocation of public capital investments was significantly reduced and resulted in a sharp decline in the level of competitiveness, output growth, and living standards.

In the context of regional competitiveness, the role of state and local government is indicated by its policies and regulations that help expand the capacity of both entrepreneurs and enterprises. State and local government policies attempt to provide opportunities for all enterprises to gain higher returns on their investments and succeed in the face of global market competition. One of the focuses of regional competitiveness is also to induce the creation of new entrepreneurs (Audretsch and Keilbach 2004). The implementation of decentralization in 1999 has introduced a new dynamic to the aspect of regional competitiveness as regions play a key role in governing and promoting growth using their own development strategies including optimization of their public capital expenditure.

This research paper is to analyze the impact of public capital investments on the output growth of medium enterprise in Indonesia using a number of data at the state (provincial) level. ${ }^{1}$ Public capital investment model at the state level is analyzed in rela-

1 Data are collected from various Indonesian government agencies among others are the Ministry of Finance, Ministry of Cooperative and Small-Medium Enterprise, and Central Bank of Indonesia. 
tion to Gross Domestic Product (GDP) of three types of medium enterprises in Indonesia from 1997-2002. GDP data of medium enterprises is interpolated based on the sample survey of Small-Medium Enterprises, which is conducted yearly by the Central Statistic Bureau. The survey method of SmallMedium Enterprises is direct interview and self enumeration. As for the factor determinant, the model includes the two types of public capital investments that are assumed to be productive: transport and educational infrastructure. Empirical analysis with the OLS method is employed to test the model.

\section{Literature Survey}

The relationship between public capital investments and economic growth is driven by the goal of government to allocate resources optimally. The two key questions are whether the government has efficiently allocated resources and whether resources have been productive in supporting growth. On the first issue, the efficiency of government is considered as a key input in determining which economic activities affect the productivity of resources and output growth. This section focuses on debates regarding the issue of productivity of public capital investments, primarily the composition between productive and unproductive public capital investments. The composition of public capital investments is crucial to identify whether to raise or reduce certain components of public capital in order to increase output growth (Devarajan 1996). A classic example is the choice between spending on physical and human capital that can be a complex issue as it depends on several variables that are unique in each country or region.

Literature on public capital investments and economic growth has made a key distinc- tion between public capital investments that is consumed by households and those that complement private sector production. Whereas the effect of public capital investments through the provision of public goods and services delivery is generally negative in the household sector, the result is mixed if public investment complements private sector production. Negative results are associated with the concept of crowding-out as a result of higher taxes that are used to finance public capital investments. Crowding-out refers to the situation where public capital acts as a substitute for private capital that hinders incentives for the private sector to invest. Yet, empirical studies found in balance that accumulation of public capital investments stimulates private investments (Munnell 1992).

Previous studies have linked productivity of public capital investments with output growth, and also with factor productivity. In addition, public capital stock is also seen as an asset to enhance productivity of private capital, increase investment rate of return and thus encourages new investments (Munnell 1992). A study by Aschaeur (1989) suggests that public capital investments are highly productive since they pay for themselves in the form of tax revenues during the operation of the assets. The study found that the rate of return of public capital investments is actually high despite the fact that governments may not always be efficient. Using the same method, Munnell (1990) came up with the same results in which a 1 percent increase in the stock of public capital would increase output by 0.34 percent. This implies that the marginal productivity of public capital is 60 percent and for private capital is only 30 percent. Many have criticized the validity of the results considering that private capital is mostly utilized in production. In contrast to 
this, some public capital investments are used in government programs that do not count towards aggregate output (Munnell 1990).

The inconclusive results of empirical analysis on the positive effect of public capital on private capital after several studies by Aschaeur (1989), Munnell (1990), Eisner (1991), Holtz-Eakin (1994), and Garcia-Mila (1996), have brought a new dynamic to the issues as they relate to regional economics. Besides the role of state and local government, the physical and spatial aspects of regions should be considered. One of the arguments is based on the exclusion of network effects in which the positive effect of public capital in a region is not only determined by the capital formation within the region, but also affected by the capital formation outside the region (Boarnet 1998). As an example, an integrated public infrastructure between neighboring regions will increase accessibility and mobility of factors of production. This will induce spillover effects referring to the new economic geography theory, which argues that increasing return to scale is a result of positive externalities and economies of scale. This provides a rationale for governments to internalize externalities and costs that are associated with economies of scale (Devarajan 1996).

Another dimension of public capital investments that is commonly debated is the justification of government intervention. In theory, market failure justifies government intervention in the form of capital investments or through various regulatory and fiscal incentives, although it may result in the inefficiency of resource allocation or constraints on business enterprise. Many opponents of government intervention argue that markets can work efficiently without government involvement. It is also argued that pri- vate capital stock is not fully influenced by public policy instruments (Acs and Storey 2004). Yet, the issue lies with the fact that private sectors are often hesitant to get involved with public capital investments, particularly in developing countries due to the risk of low rate of return and longer periods of investments. This eventually could create a disequilibria market and equity problems that require government involvement through policies and regulations.

\section{Model Specification and Estimation}

The model of government spending is based on the assumption that government investment is a complement to private sector production. Following Barro's (1990) model, the model assumes that all government spending is productive and the utility function maximizes both private consumption and public capital stock. This also refers back to the previous work of Arrow and Kurz in 1970 that argues that private production benefits from the service of public capital investments. In the neoclassical theory, this provides a rationale for government involvement in the market economy through public investments in order to support private sector development and economic growth. Yet, public capital investment does not affect the steady-state growth rate in the neo-classical view and therefore the effects of public investment on capital investments are temporary. The introduction of endogenous growth theory that focuses on long-term growth rate has changed the dynamics on the issue of public capital investment. Specific public capital investments are considered more productive in sustaining longterm growth. Education and infrastructure is typically first on the list of productive public capital investments. 
Macroeconomists argue that public capital stock is an important factor input in the production function (Gramlich 1994). Modification to the aggregate production function in the endogenous growth theory to include public capital stock has been followed by a number of researches after Aschaeur's seminal papers in 1989. The basic production function with private capital stock $K$ and labor force $L$ is written as:

$$
\mathrm{Y}=\operatorname{Af}(\mathrm{K}, \mathrm{L})
$$

$A$ represents total factor of productivity in which the neo-classical model defines as a residual due to technological progress that changes over time which are exogenous from the production decision. In the endogenous growth model, $A$ is considered as a stock of ideas or knowledge that accumulates and stimulates technological changes. Technological change is influenced by the level of investment in education and $R \& D$ to a certain degree (Romer 1990 as discussed in Acs and Storey 2004)

In the government spending model that was proposed by Aschaeur and others, $A^{*}$ is a function of productive public capital stock that is provided by government $(G)$ to accelerate growth and long-term development. The productivity factor of public capital stocks is deemed as the measurement for regional competitiveness. In this regard, only public capital stocks that support process of production are considered. The production function that incorporates public capital stock is rewritten as follows:

$$
\mathrm{Y}=\mathrm{A} * \mathrm{f}(\mathrm{K}, \mathrm{L}, \mathrm{G})
$$

In this research, $K$ is a function of private financial capital in the form of credit that specifically provides for medium enterprises, in addition to transport infrastructure that is financed by the government. $L$ is a function of human capital that influenced by educational infrastructure and also financed by the government.

The main issue with expanding public capital stock through investment is that it takes a longer period for states to get a return from their investment (Gramlich 1994). Hence like other public goods, state government will be compensated for their services in providing public goods through higher revenues from taxes and charges. Better utilities, infrastructure and transport systems will be the driver for new businesses, job creation and eventually economic growth. Thus, public capital investments should result in either constant or increasing return to scale as postulated in the endogenous growth model.

Econometric modeling is used to identify which state's capital investment is more productive in supporting the output levels of medium enterprises. Two types of state capital investments are considered critical to support the growth of medium enterprise are included in the model. First is educational infrastructure in the form of schooling facilities and equipments. The second type is transport infrastructure that includes the transport network and its support facility, such as rail and road networks, logistic and passenger stations, ports. Transport infrastructure is considered key for private sector development as factor mobility affects the way resources are allocated by business enterprises. As a control variable, the model utilizes labor productivity in relation to output, private capital investments, and private financial support for a specific sector of medium enterprise. 
Another significant attribute of the specification is the division of medium enterprise into three sectors: industrial sector, trading sector, and service sector. ${ }^{2}$ Using this classification, the model attempts to identify the impact from public capital investment to each sector of the medium enterprise. Different characteristics of each sector of medium enterprise may potentially affect the appropriate choices and incentives that best serve its needs.

The method of ordinary least squares (OLS) is used to estimate two models. Models 2 are to identify the magnitude of the impacts from public and private capital investments on the output growth of medium enterprises. It has been argued that private capital investments are typically more productive than public capital investments in supporting growth. Private capital financing supports medium enterprises through a variation of loans both short and long term that fit for a specific firm or industry. Public capital investments on the other hand are influenced by the quality of state institution and effectiveness of government's development strategies.

Specification in Model 1:

$$
\begin{gathered}
\text { Y-IND }_{t}=\alpha+\alpha_{1} \text { CAP }_{t}+\alpha_{2} I_{N V}+\alpha_{3} \text { FIN- } \\
\text { IND }_{t}+\alpha_{4} \text { LAB }_{\mathrm{t}} \mathrm{IND}_{\mathrm{t}}+\varepsilon
\end{gathered}
$$

Y-TRD $_{t}=\alpha+\alpha_{1}$ CAP $_{t}+\alpha_{2} \operatorname{INV}_{t}+\alpha_{3}$ FIN-TRD $t+\alpha_{4}$ LAB-TRD $_{t}+$ $\varepsilon$.

$$
\mathrm{Y}-S V C_{\mathrm{t}}=\alpha+\alpha_{1} \mathrm{CAP}_{\mathrm{t}}+\alpha_{2} \mathrm{INV}_{\mathrm{t}}+\alpha_{3}
$$
FIN-SVC $_{t}+\alpha_{4}$ LAB-SVC $_{t}+\varepsilon$
Models 1 is the adaptation of Aschaeur's production function where $G$ represents the growth level of public capital investment. Since the composition of public capital investment has been identified as a key factor of growth (Devarajan 1998), the second empirical analysis uses two different types of public capital investment in the model. All variables are expressed in term of ? growth

Specification in Model 2:

$$
\begin{aligned}
& \text { Y-IND }_{t}=\alpha+\alpha_{1} \text { CAP-EDU }_{t}+\alpha_{2} \text { CAP- } \\
& \text { TRN }_{\mathrm{t}}+\alpha_{3} \text { LAB-IND }_{\mathrm{t}}+\alpha_{4} \\
& \mathrm{INV}_{\mathrm{t}}+\varepsilon \\
& \text { Y-TRD }_{t}=\alpha+\alpha_{1} \text { CAP-EDU }+\alpha_{2} \text { CAP- } \\
& \text { TRN }_{t}+\alpha_{3} \text { LAB-TRD }_{t}+\alpha_{4} \\
& \mathrm{INV}_{\mathrm{t}}+\varepsilon \\
& \mathrm{INV}_{\mathrm{t}}+\varepsilon
\end{aligned}
$$

The description of the variables is as follow (measured at the state level aggregate):

$\Delta Y \quad$ : Output growth of medium enterprise (GDP growth)

$\triangle C A P \quad:$ Growth of public capital investment

$\triangle C A P-E D U:$ Growth of public capital investment in educational infrastructure

$\triangle C A P-T R N$ : Growth of public capital investment in transport infrastructure

$\triangle L A B \quad:$ Growth of labor output

$\Delta I N V \quad:$ Growth of private capital investments

$\triangle F I N \quad$ : Growth of private loan financing for small-medium enterprise

${ }^{2}$ In this study, the industrial sector of medium enterprise excludes industries that are related with natural resource exploration (oil and gas). 
The three main sectors of medium enterprises are identified as follow:

IND (Industrial Sector), TRD (Trading Sector), SVC (Service Sector)

Longitudinal panel data consist of aggregate data from 30 states in Indonesia. The time period of the data spans from $1997-$ 2002, which covers the period of 1997- 1998 financial crisis. This will provide an opportunity to test whether medium enterprises were impacted by the financial crisis after which the economic recovery took place until $2002 .^{3}$ Some argued that small-medium enterprises actually survived the crisis since they pro- duced consumption goods and services and most of them did not borrow from the bank (Partomo 2004). Small-medium enterprises were also more flexible and they benefitted from a number of market reforms that used to be the barrier to entry for small-medium enterprises.

Due to the utilization of aggregate data, the model presumes that there are no fundamental differences in terms of the structure and type of medium enterprise across states. As a result, pooled-regression with OLS can be utilized for this panel data in which the constant-coefficient method is used as the basic assumption.

Table 1. Data Statistics (Million Rp in Current Prices)

\begin{tabular}{clcccc}
\hline & \multicolumn{1}{c}{ Indicator } & Mean & SD & Minimum & Maksimum \\
\hline $\begin{array}{c}\text { Medium } \\
\text { Enterprise in }\end{array}$ & GDP & $45,810,290$ & $13,117,957$ & $28,993,652$ & $65,683,800$ \\
Industrial Sector & Working Capital Loan & $8,634,400$ & $2,016,204$ & $6,127,800$ & $12,186,700$ \\
$\begin{array}{c}\text { Medium } \\
\text { Enterprise in }\end{array}$ & GDP & $34,184,642$ & $13,105,615$ & $17,360,596$ & $55,111,800$ \\
$\begin{array}{c}\text { Trading Sector } \\
\text { Medium }\end{array}$ & Working Capital Loan & $5,084,400$ & $1,544,602$ & $3,618,100$ & $7,206,500$ \\
$\begin{array}{c}\text { Enterprise in } \\
\text { Sector Sector }\end{array}$ & Working Capital Loan & $4,895,617$ & $2,930,824$ & $2,672,500$ & $9,103,900$ \\
\hline
\end{tabular}

Table 2. Allocation of Capital Expenditure

\begin{tabular}{lcccccc}
\hline & $\mathbf{1 9 9 7}$ & $\mathbf{1 9 9 8}$ & $\mathbf{1 9 9 9}$ & $\mathbf{2 0 0 0}$ & $\mathbf{2 0 0 1}$ & $\mathbf{2 0 0 2}$ \\
\hline \% Transport Infrastructure & 21.58 & 23.55 & 27.18 & 20.71 & 22.87 & 20.88 \\
\% Transport Infrastructure & 7.73 & 6.24 & 4.82 & 9.28 & 13.35 & 15.79 \\
\hline
\end{tabular}

${ }^{3}$ IMF assumed that Indonesia's annual growth rate was restored in the vicinity of 5 to 6 percent by 2002, with an annual inflation target of below 5 percent (https://www.imf.org/external/np/exr/ib/2000/062300.htm\#box3). 


\section{Empirical Results}

The outcome of the regression analysis from the first model (see Table 3) suggests that only medium enterprises in the industrial and trading sector benefited from public capital investments between 1997 and 2002. Yet, the estimates of the regression are not statistically significant, which indicates that only specific types of public investments were significantly productive. Such public investments that are considered productive are infrastructure, health and education. Subsequent analysis will look at the infrastructure and education spending in more detail to see whether there is indeed a positive correlation between productive public and growth.
Investments in general are crucial to support output growth of medium enterprises in all sectors that are observed in this study and the impact is particularly significant in the industrial and trading sector. A one percent increase in the level of private investments is associated with 0.01 percent increase in the industrial sector and 0.03 percent in the trading sector. Both estimates are statistically significant at the five-percent level.

Besides investments, another aspect of private sector involvement in the growth of medium enterprises is related to loan financing. Providing loan financing through a diverse loan program is considered crucial for many medium enterprises as they are typically faced with difficulty to raise capital to replace

Table 3. Dependent Variable: GDP Growth of Medium Enterprises in 3 Sectors with tstatistics in parentheses

\begin{tabular}{lccc}
\hline & $\begin{array}{c}\text { Y-Industrial } \\
\text { (Spec. 3) }\end{array}$ & $\begin{array}{c}\text { Y-Trading } \\
\text { (Spec. 4) }\end{array}$ & $\begin{array}{c}\text { Y-Service } \\
\text { (Spec. 5) }\end{array}$ \\
\hline CAP & 0.08 & 0.05 & -0.13 \\
& $(0.80)$ & $(0.27)$ & $(-0.87)$ \\
INV & 0.01 & 0.03 & 0.19 \\
FIN & $(3.46)^{* *}$ & $(2.76)^{* *}$ & $(0.56)$ \\
LAB & -0.19 & 0.19 & -0.53 \\
& $(-1.60)$ & $(2.60)^{* *}$ & $(-0.22)$ \\
Adj. R-sq. & -0.13 & 0.65 & 0.47 \\
\hline
\end{tabular}

* Significant at 0.01 level

** Significant at 0.05 level 
machinery or improve the quality of their human resources. ${ }^{4}$ Yet, only medium enterprises in the trading sector that benefited from loan financing. A one percent increase in the level of loan financing would boost the GDP of medium enterprises in the trading sector by 0.19 percent. This result from the model is statistically significant at 0.05 levels.

It is possible that firms and businesses have not utilized loan financing that they received in an effective or productive way. Many of the business enterprises were also defaulting on their loans since they used the loans for expenses that did not support an expansion or improvement of their businesses. Hence this is not likely to be the case in the trading sector where business enterprises are dependent on cash liquidity to run their businesses within a short period of time. Short term loans are more effective and they may have a lower level of delinquency since traders with bad records would have difficulty to get a new loan.

An increase in the labor output has robustly increased the GDP of medium enterprises in the trading sector. A one percent growth output per worker is correlated with a 0.65 percent increase in the GDP of the medium enterprises in the trading sector and the estimator is statistically significant at 0.01 levels. This result is further supported by the fact that the trading sector was the most productive medium enterprise sector during the period of observation in comparison to industrial and service sectors.
The debate over productivity of certain public capital investments initiated the following analysis in which the model disaggregates public capital investments into two types: transport and educational infrastructure. The underlying assumption is that public capital investments in transport and educational infrastructure would have a significant effect on the productivity and growth of medium enterprises. Despite Aschaeur's argument that all public capital investments are productive, about two-thirds of total investment in the central government budget in Indonesia is allocated for current expenditures $^{5}$ and only one-third is used for financing capital investments (Blane 2005).

Government bureaucracy and inefficiency are also commonly blamed for the low productivity in public capital investments. The growing of red-tape bureaucracy along with corruption and rent-seeking in state and local governments has been identified as one of the impediments for new investments. These inefficiency factors have been a significant problem in Indonesia for decades and it is evident by the low competitiveness level of the country despite a steady increase in the growth rate.

Public capital investment in transport infrastructure was productive during the period of observation from 1997 to 2002 (see Table 4). Public capital investment in transport infrastructure supported higher growth of GDPs from medium enterprises in all sectors, particularly the trading sectors. A one

4 In Indonesia, access to capital financing for small and medium enterprise has been offered by State Owned Banks and Cooperatives. Cooperatives mainly support the financing in the agricultural sector as well as home industries. Several issues have been identified with loan programs for small medium enterprises. First, there was asymmetry information and the fact that many loans targeted certain sectors of the industry. Second, there were a number of collusion activities that occur between borrowers and financial institutions.

${ }^{5}$ Some government spending may not necessarily have an effect on private sector growth. Current expenditure is to cover salary of government employees and costs to run the government institutions. 
Table 4. Dependent Variable: GDP Growth of Medium Enterprises in 3 Sectors with tstatistics in parentheses

\begin{tabular}{lccc}
\hline & $\begin{array}{c}\text { Y-Industrial } \\
\text { (Spec. 6) }\end{array}$ & $\begin{array}{c}\text { Y-Trading } \\
\text { (Spec. 7) }\end{array}$ & $\begin{array}{c}\text { Y-Service } \\
\text { (Spec. } 8)\end{array}$ \\
\hline CAP-EDU & -0.05 & -0.06 & 0.01 \\
CAP-TRN & $(-1.08)$ & $(-1.90)$ & $(0.03)$ \\
& 0.06 & 0.09 & 0.02 \\
INV & $(5.07)^{* *}$ & $(6.35)^{* *}$ & $(5.38)^{* *}$ \\
& 0.01 & 0.04 & 0.12 \\
LAB & $(0.14)$ & $(13.21)^{*}$ & $(0.61)$ \\
& 1.08 & 0.88 & 0.06 \\
Adj. R-sq. & $(0.92)$ & $(11.01)^{*}$ & $(0.05)$ \\
\hline
\end{tabular}

* Significant at 0.01 level

** Significant at 0.05 level

percent increase of public capital investments in transport infrastructure resulted in 0.09 percent growth in GDP of medium enterprises in the trading sector and the effect is statistically significant at 0.05 level. Trading enterprises are mainly involved with transporting goods to domestic and international markets.

Transport systems, particularly road networks are also one factor that can support mobility of factor inputs in the process of production. Factor inputs include not only raw material and equipment used in the production, but also labor. By investing in a strategic transport infrastructure, both factor mobility and economic activities can be integrated in the local and national level.

Spending on educational infrastructure has been the main priority of government in developing countries in order to improve the quality of human capital. In theory, investing in human capital brings positive effects to the economy due to the development of knowledge that supports economic activities. Supporting literature on endogenous growth argue that human capital development has a potential to gain increasing returns through the knowledge spillover and positive externalities. The spillover effects of human capital development are critical as the main source of growth and development. Hence, the empirical results in this study could not determine the significant relationship between public capital investment in education and output growth of medium enterprises. Perhaps the type of education spending was not appropriate or the product of education itself did not fit with the need of medium enterprises.

Looking at the stages of development in developing countries, there is a valid reason why investing in physical capital, such as building road networks, ports, power generator, and water distribution is more produc- 
tive for private sector growth. In the first stage of development, government policies and regulations focus on supporting the transition from agricultural to industrial economy. Consequently, transport infrastructure becomes particularly critical to support mobility of factor inputs and production output. Many of the enterprises are labor intensive that require low wages and less educated workers.

The second stage of development refers to the transition from an industrial to service based economy as a means to further integrate the local economy with global markets. ${ }^{6} \quad$ Firms and industries aim to improve the quality of human resources to maintain their competitive advantage. Government support in improving educational quality is critical and becomes as important as investing in transport infrastructure.

The result of the empirical analysis as shown in Table 2 indicates that labor output is highly correlated with the GDP of medium enterprise. A larger effect was particularly evident in the industrial and trading sector, which employs a large number of workers in the process of production compared to the service sector. This pattern is consistent with the fact that the GDP of medium enterprises in industrial and trading sectors has been increasing, while it has declined in the service sector as shown in the Figure 1.

The GDP of medium enterprises in Indonesia has steadily increased in the industrial and trading sector after the 1998 financial crisis, but that was not the case in the service sector. The development of medium enterprises in the service sector was not as expected despite the assumption that the service sector can be more flexible compared to two other sectors. The fact that most service sector enterprises are located in urban areas provides an opportunity to agglomerate and better adapt to negative externalities during the crisis.

\section{Figure 1. GDP Growth of Medium Enterprise in 3 Sectors}

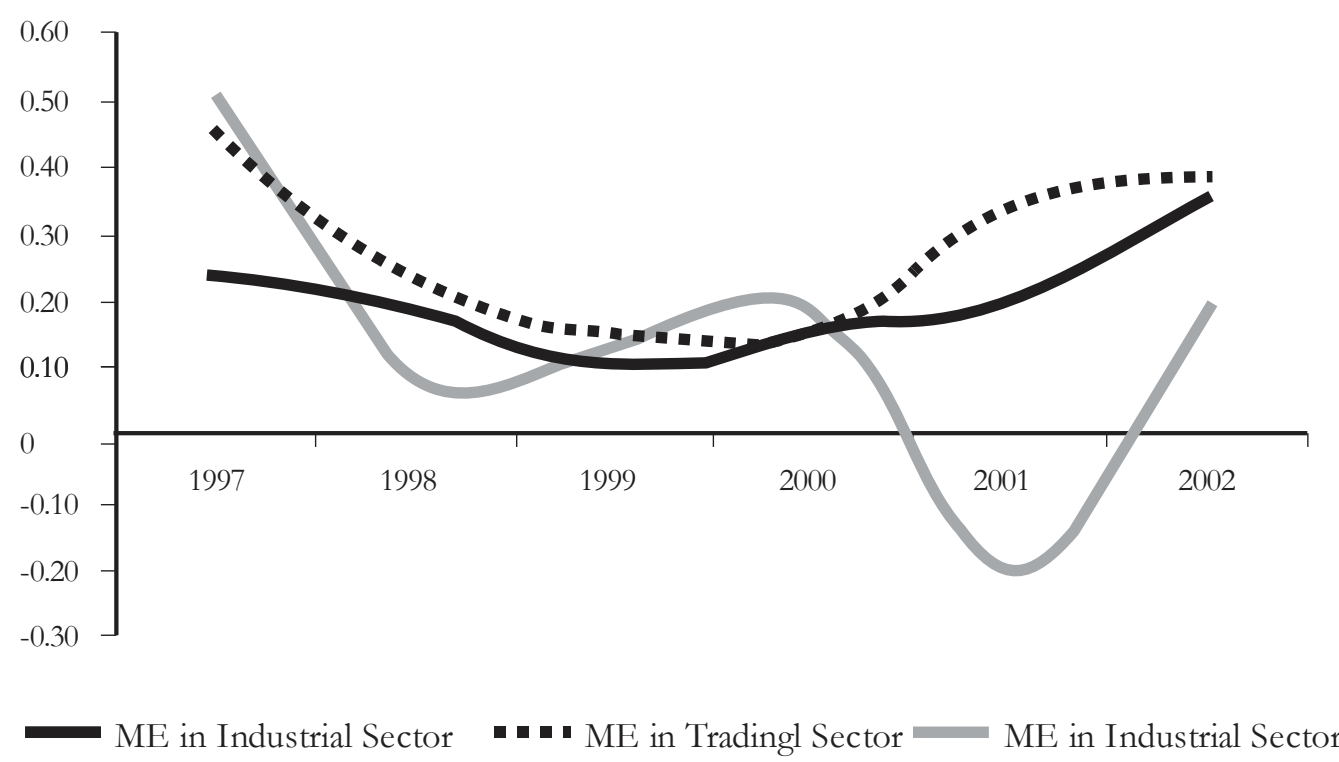

\footnotetext{
${ }^{6}$ Service sector provides services rather than goods, which among others are professional, finance, health care. Medium enterprises in the service sector also include some of the informal sector. The informal sector in many developing countries employs a large numbers of low educated workers and thus offsetting the unemployment.
} 
Figure 2. Growth of SME Working Capital Loan and Private Investments

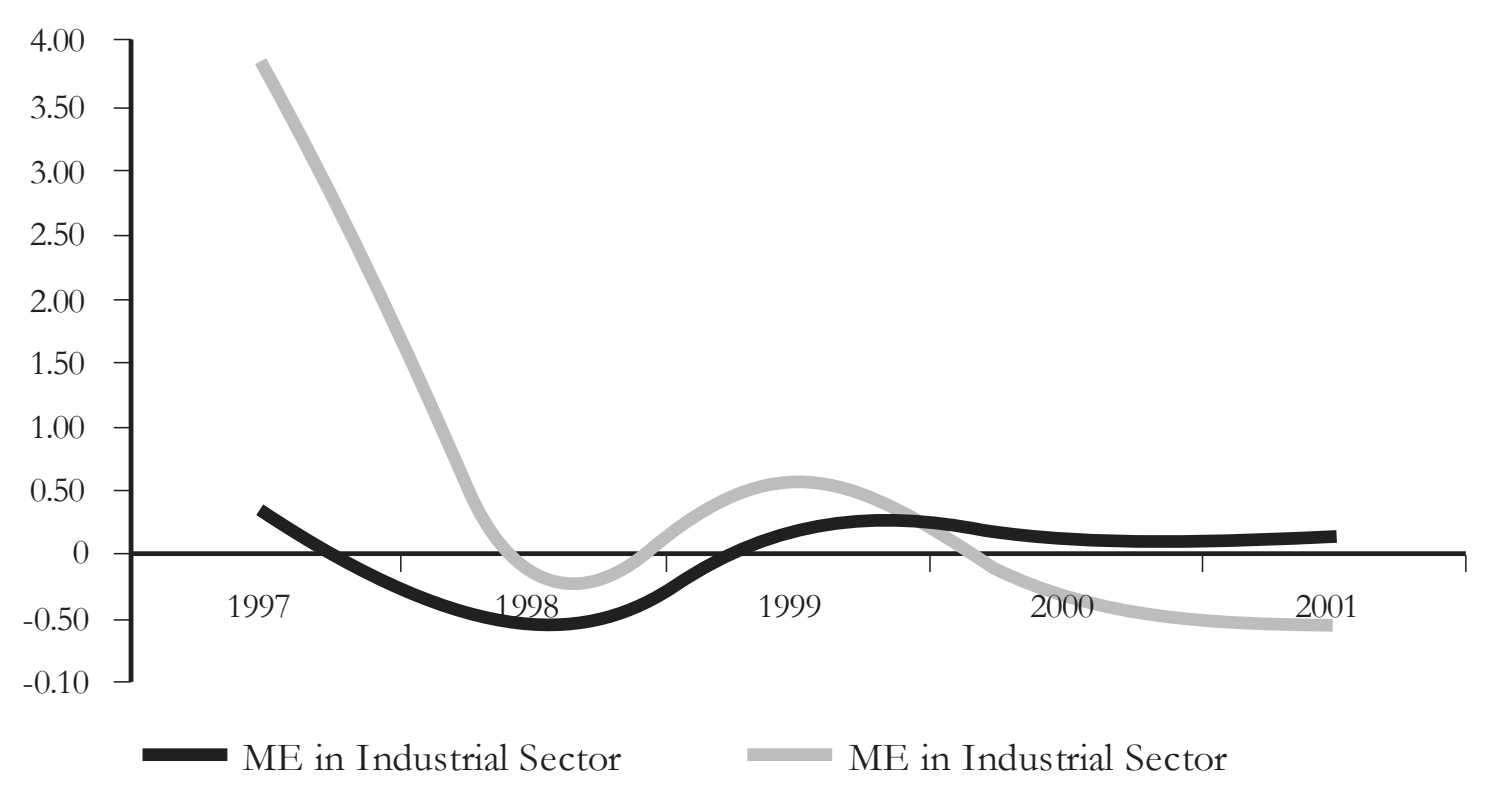

Despite the extent of the financial crisis that deters investments and financial resources, medium enterprises in the industrial and trading sector were able to maintain their GDP. One possible explanation is the different scale and size of markets that medium enterprises serve. The service sector is greatly influenced by the local economy, which was more at risk during the 1998 crisis, while medium enterprises in the industrial and trading sector had supported by global market through export. It is also important to note that spending in transport infrastructure experienced a drastic decrease after the crisis occurred in 1998, but it did not lower the output growth of medium enterprise in the industrial and trading sectors that are largely affected by transport infrastructure. This provides an evident that medium enterprises in the industrial and trading sectors have managed to become more efficient and improve their productivity following the crisis.

Consistent with the result from the first model, the second analysis also shows that private capital investments have a positive correlation with all sectors of medium enterprise. Private capital investments could potentially stimulate the establishment or reinvention of medium enterprises, but it does not warrant an increase in the level of output. As shown in Figure 2, private capital investment experienced a decline during the period of the crisis before it returned to a steady increase as the economy was recovering. Many attributed the downside of private investments during the crisis to the lack of infrastructure development and economic stability.

Government spending on transport infrastructure is historically higher than spending on educational infrastructure before the 1998 financial crisis. This again proves the point that transport infrastructure was the main priority of state governments. Hence, the crisis forced a decline in public capital investments due to government budget constraints. Aging infrastructure and a limited budget for capital improvements or new investments has eventually impacted the competitiveness level of Indonesia. 
Figure 3.Percentage Annual Growth of Capital Expenditure (Capex) in Transport Infrastructure and Educational Infrastructure

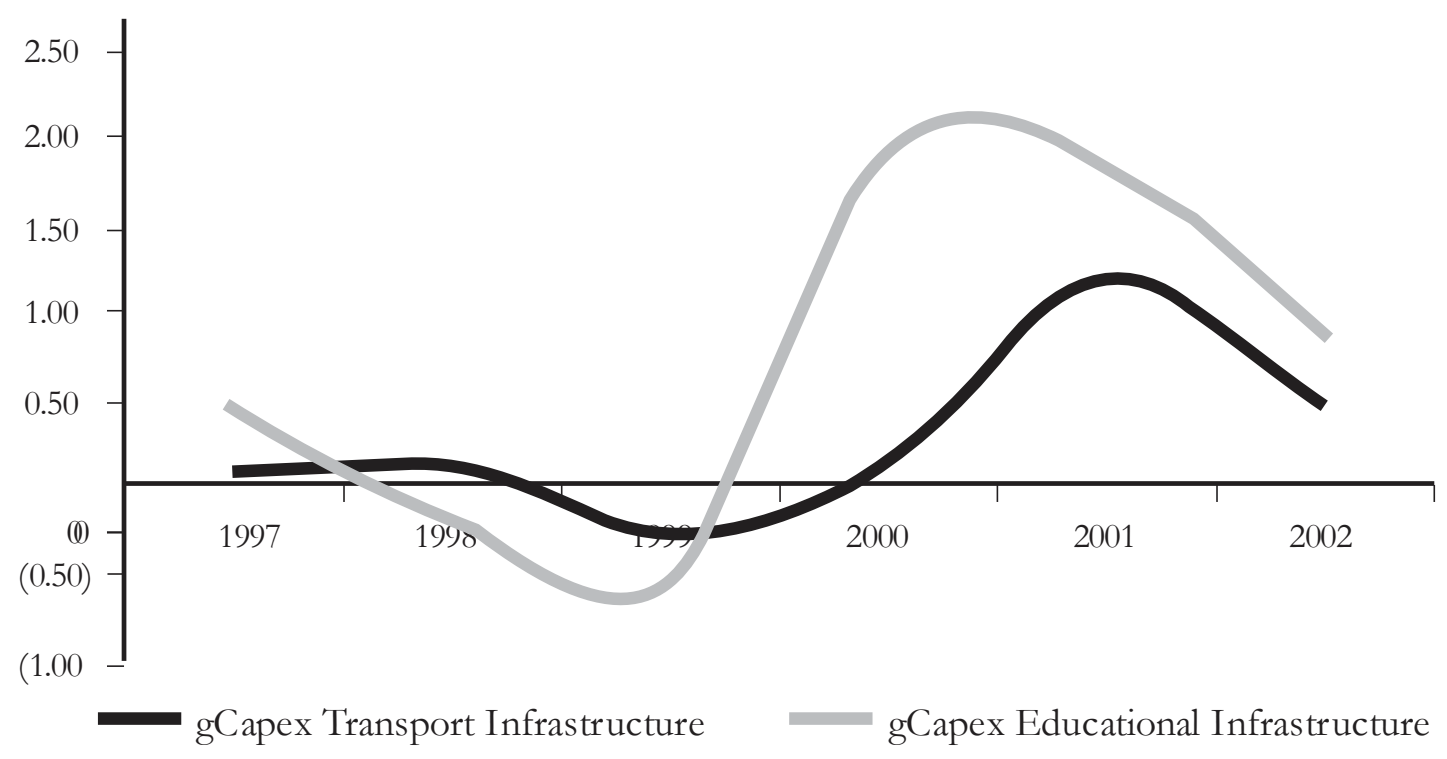

\section{Conclusion}

It is evident that investing in transport infrastructure in Indonesia should support the growth of medium enterprises. During the period of financial crisis in which public capital investments were decreased significantly, medium enterprises in Indonesia particularly in the industrial and trading sectors were still able to maintain a positive growth. One of the supporting factors is the ability of state government to keep the level of capital investments for transport infrastructure although the total state capital expenditure was dropped due to lower state revenue. Thus, it is critical for state governments to be able to increase or at least maintain the allocation of capital expenditure for transport infrastructure rather than depend on private investments. Nevertheless, it has been argued that transport infrastructure is still undersupplied and therefore more public capital investments are needed, either fully financed by the government or through Public-Private Partnerships (PPP).

Investing in educational infrastructure is found to be insignificant but does not mean that improving the quality of education and human capital development should be undermined. On the contrary, human capital is a critical element in the development of medium enterprises. Human capital and knowledge development is key in improving labor output that can be found to be significantly crucial in supporting the growth of medium enterprises. Investing in strategic R\&D along with educational infrastructure will further stimulate the development of science and technology and potentially accelerate the transition from medium to large enterprises by means of invention, innovation or optimization.

Moving forward, the government should also consider providing incentive structures that support the sustainability of medium 
enterprise as the catalyst of growth. Fiscal incentives and elimination of regulations that hinder market growth for medium enterprises would provide a competitive advantage for medium enterprises both in the domestic and international markets.

Finally, this paper is to make a case for a continuing debate on growth and development in developing countries, particularly on the issue of the role of institutions in supporting private sector development. There is no single formula on how the role of institution fits in supporting development and regional growth due to the myriad of differences in politics, socio-economic and culture in each country. Hence, by better understanding the role of institutions in regional growth and particularly medium enterprises, developing countries can formulate a more effective development strategy and incentive structure in the future.

\section{References}

Acs, Z., and D. Storey. 2004. Introduction: Entrepreneurship and economic development. Regional Studies 38 (8): 871-872

Arrow, K., and M. Kurz. 1970. Public Investment, the Rate of Return, and Optimal Fiscal Policy. Baltimore: Johns Hopkins Press.

Aschaeur, D. 1989. Is public investment productive. Journal of Monetary Economics 23 (2): 177-200.

Audretsch, D., and M. Keilbach. 2004. Entrepreneurship capital and economic performance. Regional Studies 38 (8): 949-959.

Barro, R. 1990. Government spending in a simple model of endogenous growth. Journal of Political Economy 98 (5): S103-126.

Boarnet, M .1998. Spillovers and the locational effects of public infrastructure. Journal of Regional Science 38: 381-400.

Blane, D. 2005. Indonesian local government spending, taxing and saving: An explanation of pre- and post-decentralization fiscal outcomes. Asian Economic Journal 19 (3): 291-317.

Devarajan, S. et al. 1996. The composition of public investment and economic growth. Journal of Monetary Economics 37: 313-344.

Glaeser, E. et al. 2004. Do institutions cause growth. Journal of Economic Growth 9 (3): 271-303.

Gramlich, E. 1994. Infrastructure investment: A review essay. Journal of Economic Literature 32 (3): 11761196.

Munnell, A. 1992. Infrastructure investment and economic growth. Journal of Economic Perspectives 6 (4): 189-198.

Partomo, T. S. 2004. Usaha Kecil Menengah dan Koperasi. Working Paper Series 9. Center for Industry and SME Studies, FE Universitas Trisakti, Jakarta, Indonesia.

Tambunan, T. 2007. Entrepreneurship development: Small medium enterprises in Indonesia. Journal of Developmental Entrepreneurship 12 (1): 95-118. 
